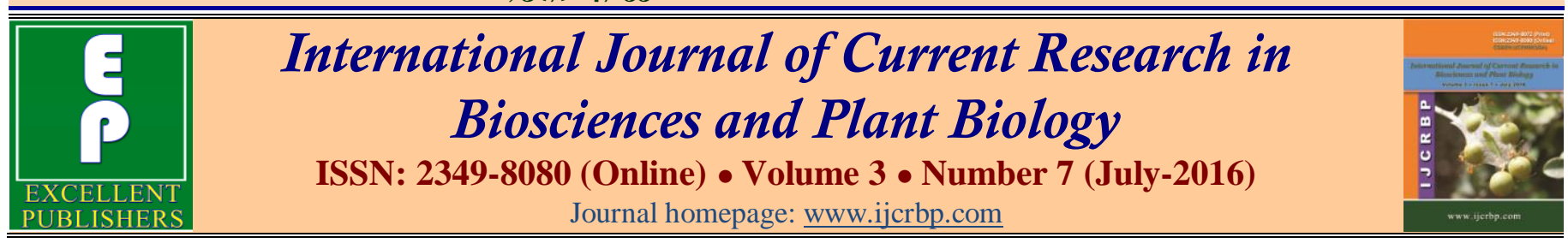

\title{
Somaclonal Variation an Aid for Sugarcane Improvement
}

\author{
P. N. Tawar ${ }^{1 *}$, K. V. Sushir ${ }^{2}$ and N. T. Meti ${ }^{3}$ \\ ${ }^{1}$ Tissue culture section Vasantdada Sugar Institute, Manjari (Bk), Pune-412 307, Maharashtra, India \\ ${ }_{2}^{2}$ Plant Breeding Section, Vasantdada Sugar Institute, Manjari (Bk), Pune-412 307, Maharashtra, India \\ 3Department of Biotechnology, Rajiv Gandhi Institute of IT and Biotechnology, Bharthi Vidyapeeth Deemed University, \\ Pune, India
}

*Corresponding author.

\begin{abstract}
Variation in natural population occurs as a result of crossing, the evolution of ecotypes, mutations and natural selection. These processes have been accelerated by plant breeders with the refinement in the techniques of selection aided by modern scientific methods. It was now find that sugarcane plants obtained through tissue culture produce a range of variation as wide as that obtained through other means. Populations of subclones were studied for economic characters and the data analyzed show a significant variation from the donor parent $\mathrm{CoC} 671$. The morphological variations viz., stem colour, intermodal alignment, leaf characters, waxiness, etc. were distinct and stable in the somaclones. The somaclonal variant TC 434 was moderately resistant to red rot disease by nodal method of inoculation as well as found drought tolerance with earliness. The present study suggests that somaclonal variation can be exploited to develop and improve agronomical traits, increase resistance to biotic and abiotic stress in crops like sugarcane.
\end{abstract}

\section{Article Info}

Accepted: 10 June 2016

Available Online: 06 July 2016

\section{Keywords}

Drought tolerance

Red rot

Somaclonal variation

Sugarcane

Tissue culture

\section{Introduction}

Sugarcane is a major crop and plays important role in socio-economic conditions of the state. The sugarcane yield levels remained stagnant or decreased in some years due to varietal degeneration and susceptibility to biotic and abiotic stresses. To ensure the genetic diversity among the cultivated varieties, it is essential to identify a few more early maturing, high yielding and high sugar varieties with resistant to biotic and abiotic stresses. The introduction of useful mutation as a means of crop improvement has a special appeal in breeding vegetatively propagated plants. The major advantages of this procedure is that, once an economically important trait is detected, it can be kept by asexually means without having to go through purification and fixation process such as have to be carried out in a sexually propagated species (Krishnamurthi, 1977). Tissue culture studies were initiated in late 1970's and protocols were standardized for tissue and meristem culture. Several clones were developed through tissue culture with improved productivity and eliminating certain defects like spines, leaf drying, disease susceptibility etc. Somaclones with smut resistance were developed from susceptible clones. Tissue culture work in sugarcane was initiated by the Hawaiian Sugarcane Planters Association Experiment Station, Hawaii, USA (HSPA) in 1961 (Nickell, 1964 and 1967). They have demonstrated that variability occurs in plants regenerated from any form of cell culture and somaclonal variation for the variation displayed among such plants. The Hawaiian work clearly demonstrated that the variability noticed in sugarcane somaclones have a clear genetic basis. 
Sugarcane varieties released so far are evolved through hybridization involving different varieties used as female and male parents. Since sugarcane varieties flowers and seed sets at sugarcane Breeding Institute, Coimbatore (Tamil Nadu, India) every year crosses are made, seedlings are raised and brought through different selections stages after careful evaluation by different research institutes to evolve new sugarcane varieties. In the present study different approach was made, without sexual cycle, somaclones were developed through tissue culture technique. CoC 671 a variety with high sucrose and good yield was under cultivation in many states like Maharashtra, northern Karnataka, Gujarat, but the variety was susceptible to two major diseases, sugarcane smut and red rot.

An abiotic stress includes drought, salinity, extreme temperature; chemical toxicity and oxidative stress are serious threats to agriculture, and natural states of environment (Wang and Altman, 2003). Drought is one of the principal environmental stresses limiting crop productivity around the world (Watanabe, 2002). It is known that somaclonal variation can bring about desirable agronomic changes in the progeny and increased sugar yield in sugarcane. Earlier studies showed variants having differentiation ability in Saccharum spp. (Liu et al., 1972; Banshali and Kishan, 1982). For imparting disease resistance $\mathrm{CoC} 671$ was used in many crosses with resistant varieties but none of the seedling population obtained with high sucrose content. Hence to obtain the disease resistance, drought tolerance with high sucrose content like CoC 671, asexual improvement through tissue culture were utilized at Vasantdada Sugar Institute's, Pune Tissue Culture laboratories. TC 434, TC 435, TC 436, TC 1190, TC 1191, TC 1193, TC 1195, TC 1196, TC 1197 and TC 1200 are some of the somaclones derived from CoC 671 for the present study.

\section{Materials and methods}

Callus culture was established from immature inflorescence of $\mathrm{CoC} 671$ sugarcane variety. Callus inductions and plant differentiation were achieved as per mentioned below.

\section{Protocol standardized for tissue culture / somaclonal variation}

Sugarcane variety CoC671 plants were grown and immature inflorescence explants were collected for raising callus. The explants material was washed several times with tap water with few drops of liquid soap. The outer old leaf base coverings were removed carefully without damaging the internal young tissue, followed by surface sterilization with $0.1 \%$ Mercury chloride for 40 to $50 \mathrm{~min}$ and followed by three washes of sterile distilled water in the laminar flow and in absolute alcohol for 2 to $3 \mathrm{~min}$. After removing outer sheaths, innermost inflorescence segments cut in to $3-6 \mathrm{~mm}$ pieces and inoculated on callus induction medium (CIM).

Murashige and Skoog (MS) (1962), basal medium, with supplemented with $2 \mathrm{mg}, 3 \mathrm{mg}$ and $4 \mathrm{mg} / 1 \mathrm{l} 2,4-\mathrm{D}$ and 5 , 10 and $15 \%$ PEG (6000) containing $10 \%$ coconut milk and $2 \%$ sucrose were used for callus induction. The $\mathrm{pH}$ of the medium adjusted to 5.8 and the cultures kept in the dark at $25 \pm 1^{\circ} \mathrm{C}$.

The well-developed calli were kept on shoot regeneration MS medium consisting $0.001 \mathrm{mg} / \mathrm{l} \mathrm{NAA}+0.0009 \mathrm{mg} / \mathrm{l}$ Kinetin and 2\% sucrose and $0.8 \%$ agar. The regenerated shoots were separated and grow further for root development on White's medium consisting $5 \mathrm{mg} / \mathrm{l} \mathrm{NAA}$ $+3 \%$ sucrose.

The well developed 293 rooted plantlets were separated and transferred to soil mixture containing small polybags and maintained $25 \pm 1{ }^{\circ} \mathrm{C}$ temperature and $70 \%$ relative humidity in the greenhouse for primary hardening. Out of which the well-hardened 199 plantlets transferred for secondary hardening in open environment. Later 167 plants were planted in ground nursery for field performance evaluation. Flowchart for the development of somaclonal variants is given in Fig. 1.

\section{Field trial}

The somaclones along with standards were planted in replicated trials in Randomized Block Design (RBD) and yield contributing characters viz., cane diameter $(\mathrm{cm})$, single cane weight $(\mathrm{kg})$, number of millable canes ('000/ha), millable height $(\mathrm{cm})$, tillering at 120 days ('000/ha) and sugar yield contributing characters viz., brix $\%$, sucrose $\%$, commercial cane sugar $\%$, juice purity $\%$ were recorded at 10 and 12 months of the crop age.

\section{Drought tolerance}

Along with the yield, quality and disease resistance the selected somaclones also screened for drought tolerance. A field experiment was conducted to select for drought tolerant somaclones derived from sugarcane variety $\mathrm{CoC}$ 
671. A split plot design was used, with contrasting irrigation levels imposed as whole plot treatments and genotypes as subplots. The unit plot size was 7 rows $\times 7$ meter. To screen for drought tolerant sugarcane somaclones, moisture stress was imposed by withholding irrigation from $60^{\text {th }}$ day after planting up to $150^{\text {th }}$ day after planting (I2) and compared with the regular irrigated crop as control (I1). Somaclones were studied for drought tolerance along with parent variety CoC 671 . Tolerance level was measured based on cane yield data. The productivity of sugarcane under moisture/drought stress conditions could be used as one of the key selection criteria for drought tolerance. In the present study, number of millable canes ('000/ha), cane yield (t/ha) and sugar yield (t/ha) of the somaclones were evaluated as field trial screening criteria.

\section{Red rot disease resistance}

Early maturing sugarcane variety $\mathrm{CoC} 671$ is highly susceptible to red rot. Maharashtra State is free from red rot disease hence for testing of red rot disease the selected somaclones derived from $\mathrm{CoC} 671$ were sent to Regional Sugarcane Research Station, Navsari, Gujarat State, India for nodal as well as plug method of inoculation. After resistance found in TC 434 this entry again sent to Sugarcane Breeding Institute, Coimbatore and Thiruvella, India for confirmation of the results at different States of India.

\section{Results and discussion} Sucrose and cane yield improvement in the
somaclones over the donor parent

Somaclones of $\mathrm{CoC} 671$ were obtained from ground nursery seedlings on the basis of brix $\%$ at $10^{\text {th }}$ and $12^{\text {th }}$ month age of crop as well as single cane weight at the age of $12^{\text {th }}$ month. Such only 10 promising somaclones were selected and advanced in rod -row trial as compared to the donor parent $\mathrm{CoC} 671$ and another standard Co 86032.The cane yield and yield contributing characters were recorded in selected somaclones along with juice quality parameters (Table 1). None of the clone was found to be significantly superior over $\mathrm{CoC}$ 671 (129.78 t/ha) while TC 436 (141.28 t/ha), TC 434 (138.80 t/ha), TC 1191 (134.09 t/ha) and TC 435 (132.30) were found numerically superior over to donor parent CoC 671.

The sucrose $\%$ at $12^{\text {th }}$ month's age of crop of somaclones viz., No. TC 1197 (21.89\%), TC 1191 (21.70\%), TC 434
(21.12\%) and TC 435 (21.04\%) were superior as compared to $\mathrm{CoC} 671$ (20.52\%) where as Commercial Cane Sugar \% recorded highest in somaclone No. TC $435(15.95 \%)$ followed by TC $1191(15.81 \%)$ and TC $1197(15.74 \%)$ respectively.

On the basis of yield and juice quality parameters six somaclones viz., TC 434, TC 435, TC 436, TC 1191, TC 1196 and TC 1197 were advanced for further study under field trial for evaluating for yield and quality parameters as compared to the donor parent $\mathrm{CoC} 671$ (Table 2). Out of six somaclones, maximum sucrose $\%$ recorded in somaclones No.TC 434 (22.53), TC 436 (22.01) and TC $1196(21.95)$ at the age of $12^{\text {th }}$ month of crop. The cane yield of somaclone TC 434 (154.06 t/ha) and TC 1191 (150.40 t/ha) recorded numerically higher over donor parent $\mathrm{CoC} 671$ (149.44 t/ha). Considering the superiority of three somaclones forwarded for further studies and evaluated with other promising somaclones developed by VSI.

The juice quality parameters along with cane yield and its contributing characters data recorded in two plants and one ratoon crops are depicted in Table 3. Among the selected somaclones derived from donor parent CoC 671, TC 434 found to be highest sucrose percentage at 10 months $(21.51 \%)$ as compared to CoC 671 (21.33\%). The improvement in the sucrose percentage also recorded in other somaclones viz., TC 2776 (21.41\%). The earliness for the maturity of canes in terms of sugar was improved through the use of somaclonal variation technology. The cane yield tones/ha for the somaclone TC 906 (140.15 t/ha) recorded significantly higher as compared to the donor parent CoC 671 (126.19 t/ha) followed with numerically higher in TC 922 (133.91 t/ha) and TC 434 (131.13 t/ha) respectively. The other parameters like CCS \% (Commercial Cane Sugar), Brix \% at 10 and 12 Months recorded in the somaclones as compared to the donor CoC 671. The maximum CCS \% was recorded in the TC 434 with $16.79 \%$ and Brix \% (24.07\%) at 12 months of age crop against donor CoC 671 (CCS$16.70 \%$ and Brix- $23.85 \%$ ) respectively. The similar improvement in somaclones over donor parent for cane and sugar yield reported by Jalaja et al. (2006) using utilization of somaclonal variation technology and mentioned about this techniques for rectifying specific defects. The data recorded in the somaclone derivatives showed that TC 434 has early maturing characters (at 10 months) with better yield. The morphological features of the donor parent $\mathrm{CoC} 671$ and the somaclonal variants given in Table 4 and Fig. 2. The same somaclone TC 434 also tested for the drought trial. 


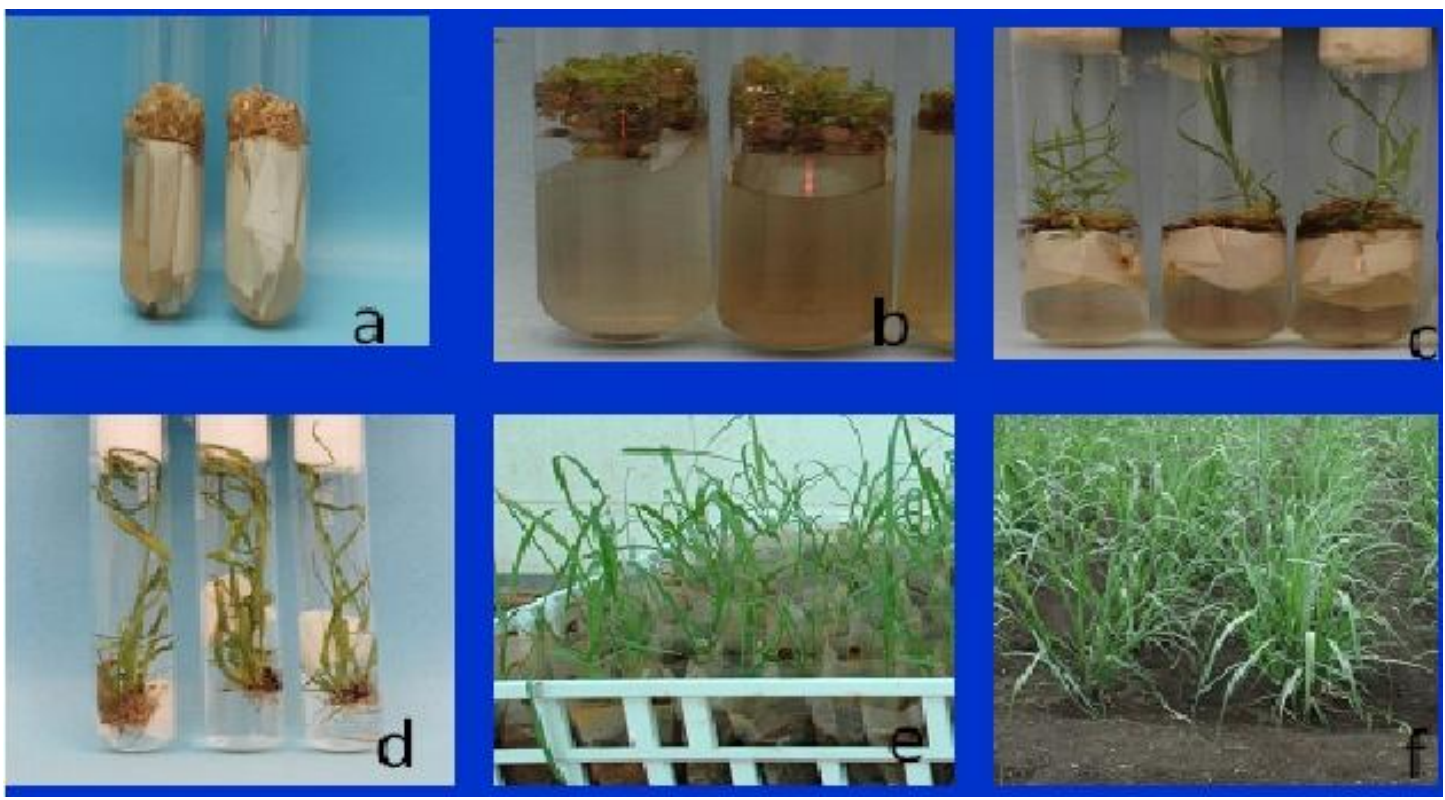

Fig. 1: Flowchart for the development of somaclonal variants.
a) Callus induction in liquid medium
b) Shoot initiation in solid medium
c) Shoot elongation in liquid medium
d) Root formation in liquid rooting media
e) Hardening in green house
f) Planting in field
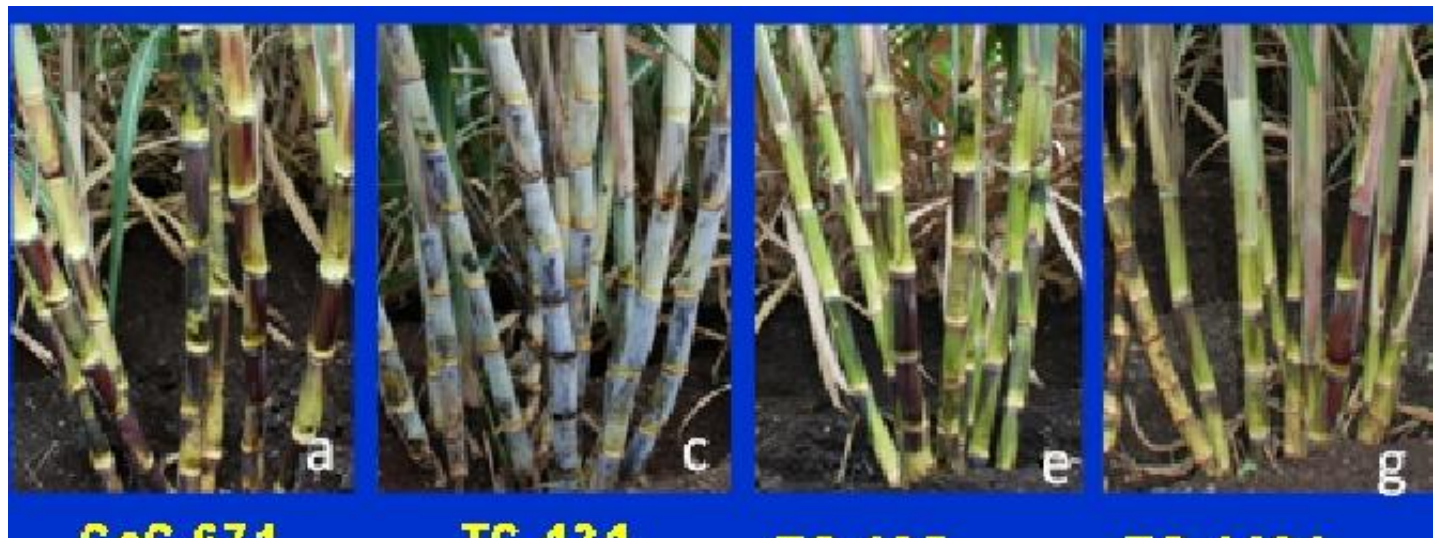

\section{Coc 671}

TC 434
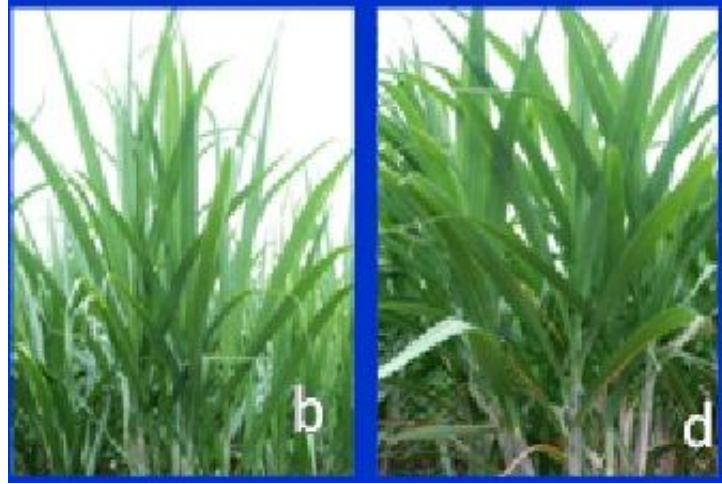

\section{TC 435}

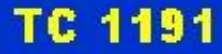

Fig. 2: Morphological variations in the somaclones derived from donor parent CoC 671.
a. Stem colour of $\mathrm{CoC} 671$
b. Leaf canopy of CoC 671
e. Stem colour of TC 435
c. Stem colour of TC 434
d. Leaf canopy of TC 434
h. Leaf canopy of TC 1191
f. Leaf canopy of TC 435
g. Stem colour of TC 1191

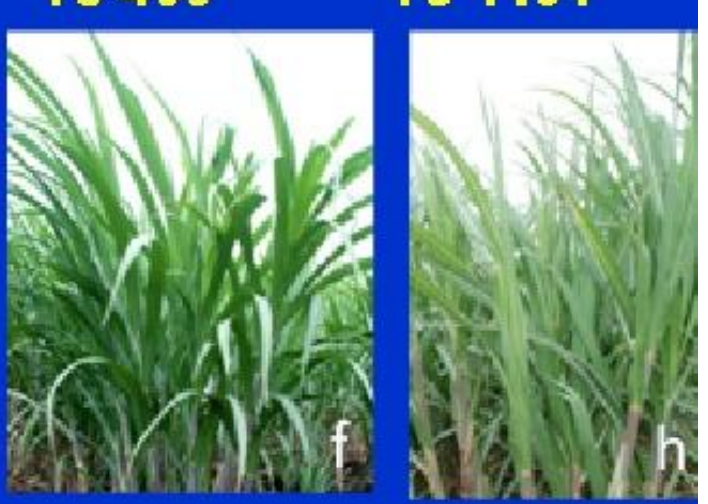


Table 1. Field and quality performance of somaclones derived from CoC 671 sugarcane variety in preliminary trials

\begin{tabular}{|c|c|c|c|c|c|c|c|c|c|c|c|c|c|}
\hline $\begin{array}{l}\text { Sr. } \\
\text { No }\end{array}$ & Somaclones & $\operatorname{CCS}(t / h a)$ & $\begin{array}{l}\text { Cane yield } \\
(\mathrm{t} / \mathrm{ha})\end{array}$ & $\begin{array}{l}\text { Cane } \\
\text { diameter } \\
\text { (cm) }\end{array}$ & $\begin{array}{c}\text { Single cane } \\
\text { weight }(\mathbf{k g})\end{array}$ & $\begin{array}{l}\text { No. of millable } \\
\text { canes/ha ('000) }\end{array}$ & $\begin{array}{l}\text { Millable } \\
\text { height of } \\
\text { cane }(\mathrm{cm})\end{array}$ & $\begin{array}{l}\text { Sucrose \% } \\
12 \text { months }\end{array}$ & $\begin{array}{l}\text { CCS \% } \\
12 \text { months }\end{array}$ & $\begin{array}{l}\text { Brix \% } \\
12 \text { months }\end{array}$ & $\begin{array}{l}\text { Sucrose \% } \\
10 \text { months }\end{array}$ & $\begin{array}{l}\text { CCS \% } \\
10 \text { months }\end{array}$ & $\begin{array}{l}\text { Brix \% } \\
10 \text { months }\end{array}$ \\
\hline 1 & TC 434 & 21.24 & 138.80 & 2.84 & 1.46 & 94.73 & 247.00 & 21.12 & 15.28 & 22.29 & 21.40 & 15.41 & 22.85 \\
\hline 2 & TC 435 & 21.08 & 132.30 & 2.95 & 1.52 & 87.27 & 247.44 & 21.04 & 15.95 & 22.00 & 20.84 & 15.06 & 22.05 \\
\hline 3 & TC 436 & 20.79 & 141.28 & 2.94 & 1.58 & 89.60 & 253.34 & 20.34 & 14.70 & 21.51 & 19.18 & 13.70 & 20.86 \\
\hline 4 & TC 1190 & 18.16 & 123.30 & 2.92 & 1.46 & 84.47 & 261.00 & 20.14 & 14.74 & 20.70 & 17.84 & 12.85 & 19.01 \\
\hline 5 & TC 1191 & 21.18 & 134.09 & 2.85 & 1.37 & 98.00 & 266.78 & 21.70 & 15.81 & 22.85 & 18.35 & 13.44 & 20.82 \\
\hline 6 & TC 1193 & 20.35 & 133.18 & 2.86 & 1.51 & 88.20 & 276.67 & 21.05 & 15.30 & 22.00 & 19.45 & 13.89 & 21.14 \\
\hline 7 & TC 1195 & 19.37 & 133.30 & 2.78 & 1.43 & 93.80 & 263.44 & 20.21 & 14.55 & 21.58 & 19.65 & 13.97 & 21.57 \\
\hline 8 & TC 1196 & 20.24 & 141.10 & 2.96 & 1.53 & 92.60 & 276.44 & 19.84 & 14.36 & 20.99 & 19.40 & 13.83 & 21.17 \\
\hline 9 & TC 1197 & 20.80 & 123.77 & 2.87 & 1.25 & 98.93 & 265.78 & 21.89 & 15.74 & 22.62 & 19.00 & 13.49 & 20.90 \\
\hline \multirow[t]{6}{*}{10} & $\begin{array}{l}\text { TC } 1200 \\
\text { Standards }\end{array}$ & 18.42 & 118.76 & 3.11 & 1.32 & 90.53 & 274.22 & 21.49 & 15.54 & 22.73 & 20.08 & 14.35 & 21.81 \\
\hline & CoC 671 & 19.27 & 129.78 & 2.78 & 1.44 & 89.83 & 248.63 & 20.52 & 14.95 & 21.33 & 20.48 & 14.68 & 22.06 \\
\hline & Co 86032 & 18.19 & 141.17 & 2.80 & 1.35 & 104.93 & 235.05 & 18.91 & 12.87 & 18.50 & 16.83 & 11.85 & 18.82 \\
\hline & $\mathrm{SE} \pm$ & 1.15 & 5.69 & 0.13 & 0.06 & 2.33 & 4.82 & 1.31 & 0.72 & 0.83 & 0.65 & 0.48 & 0.61 \\
\hline & $\mathrm{CD}^{-} 5 \%$ & 3.38 & 16.68 & 0.27 & 0.19 & 6.83 & 14.15 & 3.84 & 2.12 & 2.42 & 1.90 & 1.39 & 1.77 \\
\hline & $\mathrm{CV}$ & 10.01 & 7.43 & 2.13 & 7.79 & 4.35 & 3.22 & 2.37 & 8.37 & 6.63 & 5.78 & 5.93 & 4.97 \\
\hline
\end{tabular}

Table 2. Field and quality performance of selected somaclones derived from CoC 671 sugarcane variety.

\begin{tabular}{|c|c|c|c|c|c|c|c|c|c|c|c|c|c|}
\hline $\begin{array}{l}\text { Sr. } \\
\text { No }\end{array}$ & Somaclones & CCS (t/ha) & $\begin{array}{l}\text { Cane } \\
\text { yield (t/ha) }\end{array}$ & $\begin{array}{l}\text { Cane } \\
\text { diameter } \\
(\mathrm{cm})\end{array}$ & $\begin{array}{l}\text { Single cane } \\
\text { weight } \\
\text { (kg) }\end{array}$ & $\begin{array}{l}\text { No. of millable } \\
\text { canes/ha ('000) }\end{array}$ & $\begin{array}{l}\text { Millable } \\
\text { height of } \\
\text { cane }(\mathrm{cm})\end{array}$ & $\begin{array}{l}\text { Sucrose \% } \\
12 \text { months }\end{array}$ & $\begin{array}{l}\text { CCS \% } \\
12 \text { months }\end{array}$ & $\begin{array}{l}\text { Brix \% } \\
12 \text { months }\end{array}$ & $\begin{array}{l}\text { Sucrose \% } \\
10 \text { months }\end{array}$ & $\begin{array}{l}\text { CCS \% } \\
10 \text { months }\end{array}$ & $\begin{array}{l}\text { Brix \% } \\
10 \text { months }\end{array}$ \\
\hline 1 & TC 434 & 25.07 & 154.06 & 2.96 & 1.59 & 96.89 & 256.67 & 22.53 & 15.29 & 23.91 & 19.94 & 14.18 & 21.87 \\
\hline 2 & TC 435 & 22.20 & 148.35 & 2.99 & 1.47 & 101.00 & 246.67 & 21.08 & 14.67 & 22.89 & 21.04 & 15.07 & 22.73 \\
\hline 3 & TC 436 & 21.53 & 136.92 & 2.98 & 1.46 & 94.00 & 252.33 & 22.01 & 14.27 & 23.41 & 19.83 & 14.05 & 21.94 \\
\hline 4 & TC 1191 & 21.11 & 150.40 & 3.06 & 1.57 & 95.44 & 247.67 & 19.70 & 13.78 & 21.46 & 17.93 & 12.63 & 20.08 \\
\hline 5 & TC 1196 & 20.83 & 132.23 & 2.99 & 1.50 & 88.11 & 238.67 & 21.95 & 14.28 & 23.54 & 20.01 & 14.33 & 21.59 \\
\hline \multirow[t]{6}{*}{6} & TC 1197 & 17.81 & 120.98 & 2.84 & 1.38 & 87.78 & 256.00 & 20.65 & 14.44 & 22.67 & 19.33 & 13.68 & 21.44 \\
\hline & Standards & 22.40 & 14944 & 294 & 152 & 9799 & 24233 & 2109 & 1432 & 2303 & 1068 & 1303 & 2182 \\
\hline & Co 86032 & 24.54 & 164.44 & 2.80 & 1.68 & 98.55 & 292.67 & 20.74 & 14.09 & 22.43 & 20.13 & 14.44 & 21.68 \\
\hline & $\mathrm{SE} \pm$ & 1.98 & 7.81 & 0.33 & 0.11 & 3.42 & 11.69 & 0.79 & 0.62 & 0.59 & 0.61 & 0.49 & 0.51 \\
\hline & $\mathrm{CD}(5 \%)$ & 5.79 & 17.62 & 0.88 & 0.31 & 7.08 & 24.00 & 2.30 & 1.80 & 1.71 & 1.79 & 1.46 & 1.49 \\
\hline & $\mathrm{CV}$ & 8.24 & 12.24 & 1.03 & 2.39 & 9.21 & 12.37 & 1.20 & 1.37 & 1.36 & 1.48 & 1.17 & 1.28 \\
\hline
\end{tabular}


Table 3. Pooled of two plant and one ratoon data on cane yield, quality and their contributing characters in selected Tissue culture somaclones.

\begin{tabular}{|c|c|c|c|c|c|c|c|c|c|c|c|c|c|c|c|}
\hline $\begin{array}{l}\text { Sr. } \\
\text { No }\end{array}$ & Somaclones & $\begin{array}{l}\text { CCS } \\
\text { (t/ha) }\end{array}$ & $\begin{array}{l}\text { Cane } \\
\text { yield (t/ha) }\end{array}$ & $\begin{array}{l}\text { Cane } \\
\text { diameter } \\
(\mathrm{cm})\end{array}$ & $\begin{array}{l}\text { Single cane } \\
\text { weight (kg) }\end{array}$ & $\begin{array}{l}\text { No. of } \\
\text { millable } \\
\text { canes/ha } \\
(\cdot 000)\end{array}$ & $\begin{array}{l}\text { Millable } \\
\text { height of } \\
\text { cane }(\mathrm{cm})\end{array}$ & $\begin{array}{l}\text { CCS \% } \\
10 \mathrm{M}\end{array}$ & $\begin{array}{l}\text { CCS \% } \\
12 \mathrm{M}\end{array}$ & $\begin{array}{l}\text { Sucrose \% } \\
10 \mathrm{M}\end{array}$ & $\begin{array}{l}\text { Sucrose \% } \\
12 \mathrm{M}\end{array}$ & $\begin{array}{l}\text { Brix \% } \\
10 \mathrm{M}\end{array}$ & $\begin{array}{l}\text { Brix \% } \\
12 \mathrm{M}\end{array}$ & Fibre $\%$ & $\begin{array}{l}\text { No. of inter } \\
\text { nodes/cane }\end{array}$ \\
\hline 1 & TC 878 & 19.35 & 118.25 & 2.91 & 1.19 & 99.47 & 255.89 & 14.90 & 16.34 & 20.77 & 22.41 & 22.34 & 23.23 & 14.11 & 20.33 \\
\hline 2 & TC 1191 & 17.00 & 106.81 & 2.85 & 1.04 & 96.68 & 220.78 & 15.27 & 15.99 & 21.21 & 22.02 & 22.63 & 23.08 & 13.21 & 22.67 \\
\hline 3 & TC 906 & 22.96 & 140.15 & 3.12 & 1.31 & 103.37 & 235.56 & 14.65 & 16.33 & 20.36 & 22.45 & 21.76 & 23.41 & 14.29 & 22.55 \\
\hline 4 & TC 922 & 22.04 & 133.91 & 3.07 & 1.34 & 92.25 & 250.10 & 15.36 & 16.49 & 21.11 & 22.67 & 22.01 & 23.66 & 14.37 & 22.44 \\
\hline 5 & VSI 435 & 19.86 & 124.02 & 2.80 & 1.15 & 100.02 & 223.71 & 13.88 & 16.00 & 19.31 & 22.03 & 20.68 & 23.05 & 13.98 & 22.44 \\
\hline 6 & TC 2776 & 16.69 & 103.48 & 2.80 & 1.13 & 83.33 & 235.78 & 15.50 & 16.18 & 21.41 & 22.29 & 22.55 & 23.36 & 14.48 & 22.11 \\
\hline \multirow[t]{8}{*}{7} & TC 434 & 22.17 & 131.31 & 2.98 & 1.33 & 96.17 & 249.48 & 15.60 & 16.79 & 21.51 & 23.09 & 22.60 & 24.07 & 14.36 & 22.28 \\
\hline & Standards & & & & & & & & & & & & & & \\
\hline & CoC 671 & 21.10 & 126.19 & 2.98 & 1.45 & 87.54 & 222.05 & 15.48 & 16.70 & 21.33 & 22.93 & 22.35 & 23.85 & 14.81 & 21.44 \\
\hline & Co 94012 & 19.34 & 122.94 & 3.10 & 1.39 & 87.78 & 255.63 & 14.70 & 15.78 & 20.33 & 21.76 & 21.47 & 22.87 & 14.13 & 21.55 \\
\hline & Co 86032 & 22.82 & 145.88 & 2.96 & 1.37 & 107.29 & 226.99 & 14.35 & 15.72 & 19.82 & 21.64 & 20.89 & 22.63 & 14.39 & 21.70 \\
\hline & $\mathrm{SE} \pm$ & 1.78 & 8.36 & 0.13 & 0.06 & 8.74 & 11.76 & 0.34 & 0.20 & 0.45 & 0.27 & 0.49 & 0.28 & 0.66 & 0.95 \\
\hline & $\mathrm{CD}$ at $5 \%$ & 3.65 & 12.43 & 0.27 & 0.13 & 18.11 & 20.53 & 0.69 & 0.42 & 0.92 & 0.56 & 1.02 & 0.57 & 1.68 & 1.97 \\
\hline & $\mathrm{CV} \%$ & 9.32 & 11.63 & 5.12 & 4.91 & 11.28 & 10.03 & 2.14 & 1.54 & 2.63 & 1.48 & 2.78 & 1.44 & 2.24 & 5.31 \\
\hline
\end{tabular}




\section{Drought tolerance}

Cane yield is the product of genetic potential of a variety and environmental conditions through agronomic management. Maximum cane yield was obtained in nonstress condition i.e. in control (115.53 t/ha) where as the moisture stress reduced the cane yield up to $99.02 \mathrm{t} / \mathrm{ha}$ (Table 5). These results are supported by the findings of earlier workers (Singh et al., 2006; Inman-Bamber and Smith, 2005; Smith et al., 2005; Ghaffar et al., 2013).
The moisture stress had minimum adverse effect on TC 434. In TC 434 due to moisture stress cane yield was reduced by $4.54 \%$ over the control treatment (120.77 t/ha). The donor parent CoC 671 had noted $27.49 \%$ reduction in cane yield due to moisture stress over the cane yield obtained in control treatment (123.57 t/ha). The yield data revealed that the differences among genotypes were not significant. TC 434 has recorded higher cane yield $(123.64 \mathrm{t} / \mathrm{ha})$ over the donor parent CoC 671 (106.58 t/ha).

Table 4. Morphological differences between donor CoC 671 and selected somaclones.

\begin{tabular}{|c|c|c|c|c|c|}
\hline \multirow{2}{*}{$\begin{array}{l}\text { Sr. } \\
\text { No }\end{array}$} & \multirow{2}{*}{ Descriptor } & \multirow{2}{*}{$\begin{array}{l}\text { Donor parent } \\
\text { CoC } 671\end{array}$} & \multicolumn{3}{|l|}{ Somaclones } \\
\hline & & & TC 434 & TC 435 & TC 1191 \\
\hline \multirow[t]{2}{*}{1} & Parentage & Q 63 X Co 775 & Somaclone & Somaclone & Somaclone \\
\hline & & & CoC 671 & CoC 671 & $\mathrm{CoC} 671$ \\
\hline 2 & Stem colour (Exposed) & Purple & Reddish pink & Pink & Dark purple \\
\hline 3 & Stem Colour (Un-exposed) & $\begin{array}{l}\text { Light greenish } \\
\text { yellowish }\end{array}$ & Greenish yellow & Greenish yellow & $\begin{array}{l}\text { Light greenish } \\
\text { yellowish }\end{array}$ \\
\hline 5 & Corky patches & Absent & Absent & Absent & Absent \\
\hline 6 & Internode shape & Cylindrical & Abconoidal & Abconoidal & Cylindrical \\
\hline 7 & Internode alignment & Zigzag & Slightly zigzag & Straight & Zigzag \\
\hline 8 & Internode diameter & $2.75 \mathrm{~cm}$ & $2.63 \mathrm{~cm}$ & $2.71 \mathrm{~cm}$ & $2.78 \mathrm{~cm}$ \\
\hline 9 & Pithiness & Absent & Absent & Absent & Absent \\
\hline 10 & Internode splits & Absent & Absent & Absent & Absent \\
\hline 11 & Internode waxiness & Absent & Medium & Medium & Absent \\
\hline \multirow[t]{2}{*}{14} & a) No. of root eye rows & Two-three & Two & Two & Two-three \\
\hline & b) Arrangement & Irregular & Irregular & Irregular & Irregular \\
\hline 15 & Bud size & Small & Small & Small & Small \\
\hline 16 & Bud shape & Ovate & Round & Round & Ovate \\
\hline 17 & Bud cushion & Absent & Absent & Absent & Absent \\
\hline 18 & Bud groove & Absent & Absent & Absent & Absent \\
\hline 20 & Leaf width & Broad & Medium & Medium & Medium \\
\hline 21 & Lamina colour & Green & Dark green & Green & Green \\
\hline 22 & Leaf carriage & Open drooping & Semi drooping & Semi drooping & Open drooping \\
\hline 23 & Leaf sheath colour & Dark purple & Purple with slight green & Green with purple & Dark purple \\
\hline 24 & Leaf sheath waxiness & Absent & Medium & Medium & Absent \\
\hline 25 & Leaf sheath spines & Hard, more & Few, hard, deciduous & Few, hard, deciduous & $\begin{array}{l}\text { Few, hard, } \\
\text { deciduous }\end{array}$ \\
\hline 26 & Leaf sheath clasping & Easily detrashing & Slightly tight & Medium & Slightly tight \\
\hline 27 & Dewlap colour & Light green & Green with dark brown & Dark green & Light green \\
\hline 28 & Ligular process & Present & Absent & Absent & Absent \\
\hline 30 & Flowering & Non Flowering & Non-flowering & Non-flowering & $\begin{array}{l}\text { Flowers in south } \\
\text { Maharashtra }\end{array}$ \\
\hline
\end{tabular}

The moisture stress adversely affected on number of millable canes of all genotypes. The genotypes grown under non-stress condition i.e. control treatment has recorded maximum number of millable canes (83.97 '000/ha) as compared to the crop affected due to moisture stress (78.68 '000/ha). The decrease in number of millable canes due to moisture stress is also reported by Hemaprabha et al. (2004 and 2006) and Silva et al. (2008). Significant difference among the genotypes for number of millable canes was observed and it might be 
due to the genetic potential of the genotypes to withstand moisture stress. Among the genotypes significantly higher number of millable canes was noted in TC 434 (85.55'000/ha) over the donor parent CoC 671 (72.86
' $000 / \mathrm{ha})$. The significant difference in number of millable canes might be due to the inherent potential of the genotypes to withstand moisture stress. These results are in line with Vasantha et al. (2005).

Table 5. Effect of water stress on yield and yield attributes.

\begin{tabular}{|c|c|c|c|c|c|c|c|c|c|}
\hline \multirow{2}{*}{ Variety } & \multicolumn{3}{|c|}{ Number of millable canes (' $000 / \mathrm{ha})$} & \multicolumn{2}{|c|}{ Cane yield (t/ha) } & \multicolumn{4}{|c|}{ C.C.S. (t/ha) } \\
\hline & $\mathbf{I}_{\mathbf{1}}$ & $\mathbf{I}_{2}$ & Mean & $\mathbf{I}_{1}$ & $\mathbf{I}_{2}$ & Mean & $\mathbf{I}_{1}$ & $\mathbf{I}_{2}$ & Mean \\
\hline Co 94012 & 74.44 & 77.61 & 76.03 & 96.50 & 86.69 & 91.59 & 13.31 & 11.93 & 12.62 \\
\hline TC 434 & 88.73 & 85.55 & $87.14 *$ & 126.52 & 120.77 & 123.64 & 18.09 & 17.17 & 17.63 \\
\hline CoC 671 & 88.73 & 72.85 & 80.79 & 123.57 & 89.60 & 106.58 & 17.20 & 11.58 & 14.39 \\
\hline Mean & 83.97 & 78.68 & & 115.53 & 99.02 & & 16.20 & 13.56 & \\
\hline \multicolumn{3}{|c|}{ S.E. \pm Main Treat. } & 1.46 & & & 3.57 & & & 0.65 \\
\hline \multicolumn{3}{|c|}{ C. D. at 5\% Main Treat } & NS & & & NS & & & NS \\
\hline \multicolumn{3}{|c|}{ S.E. \pm Sub Treat. } & 3.17 & & & 3.01 & & & 0.57 \\
\hline \multicolumn{3}{|c|}{ C.D. at 5\% Sub Treat } & 9.77 & & & N.S. & & & N.S. \\
\hline \multicolumn{3}{|c|}{ S.E. \pm Interaction } & 4.49 & & & 4.25 & & & 0.81 \\
\hline \multicolumn{3}{|c|}{ C.D. at $5 \%$ Interaction } & NS & & & 1.31 & & & NS \\
\hline
\end{tabular}

$\mathrm{I}_{1}$ : Non-stress, $\mathrm{I}_{2}$ : Stress.

Table 6. Reaction of TC 434 to red rot disease in All India Coordinated Research Project on Sugarcane (AICRPS).

\begin{tabular}{lllllll}
\hline \multirow{2}{*}{ Entry } & Coimbatore & \multicolumn{3}{c}{ Thiruvella } & Navsari \\
\cline { 2 - 7 } & Plug method & Nodal method & Plug method & Nodal method & Plug method & Nodal method \\
\hline TC 434 & MR & R & MS & R & MR & R \\
Standard & & & & HS & HS \\
CoC 671 & HS & HS & HS & HS & HS
\end{tabular}

HS: Highly Susceptible, MR: Moderately Resistant, R: Resistant

The commercial cane sucrose i.e., C.C.S (t/ha) is a product of cane yield and commercial cane sucrose $\%$. The moisture stress did not affected adversely on C.C.S (t/ha). Among the somaclones highest C.C.S. (t/ha) was recorded in TC $434(17.63 \mathrm{t} / \mathrm{ha})$ over its donor parent CoC 671 (14.39 t/ha). The results are in consonance with Singh et al. (2001) and Singh et al. (2006) who reported that C.C.S. (t/ha) was not affected due to different levels of irrigation.

\section{Red rot disease resistance}

One of the major reasons of low productivity in sugarcane and sugar in the country is the incidence of red rot disease. Many varieties of sugarcane have gone out of cultivation due to incidence of this disease and several other popular and high yielding varieties are struggling for their existence (Pankaj Kumar et al., 2012). New varieties with high yielding capacity, higher sugar content along with resistance for disease especially red rot are evolved through breeding methods are requiring 8-10 years (Gill et al., 2007; Singh et al., 2008). A period of further 8-10 years is required to reach the seed of new varieties to the growers in remote villages for general cultivation. In vitro techniques can be used in competitively shorter period of time (Tiwari et al., 2010). Somaclonal variation has also been employed to develop resistant clones of sugarcane for various diseases (Sreenivasan and Jalaja, 1995; Jalaja et al., 2006). Amongst the clone, TC 434 somaclone derived from $\mathrm{CoC} 671$ found to be resistant by nodal method and moderately resistant to plug method at Thiruvella and Navsari location of India (Table 6).

\section{Conclusion}

The somaclonal variation in sugarcane in the present study resulted genetic improvement in terms of sucrose, earliness, red rot resistance along with drought tolerance in somaclones derived from the donor parent $\mathrm{CoC} 671$. The work resolved the controversy of induced mutations role in crop improvement equal to conventional hybridization particularly obtaining novel variants viz., high sugar content, multiple stress tolerance etc. where conventional breeding has many limitations. The somaclone i.e., TC 434 was identified for earliness, red rot resistance and drought tolerance may be utilized as a parent in hybridization programme for the development 
of resistant genetic stocks. In the present investigation it was found that TC 434 showed superiority in cane and sugar yield under moisture stress condition compared to their donor parent variety $\mathrm{CoC}$ 671. These results indicate feasibility and effectiveness of creation and selection of somaclone for drought tolerance.

\section{Conflict of interest statement}

Authors declare that they have no conflict of interest.

\section{Acknowledgement}

Authors are thankful to Director General, Vasantdada Sugar Institute, Pune for the facilities provided for carrying out the work.

\section{References}

Banshali, R.R., Kishan, S., 1982. Callus and shoot formation from leaf of sugarcane in tissue culture. Phytomorphol. $32(2 / 3), 167-170$.

Ghaffar, A., Mudassir, M. A., Sarwar, M. A., Nadeem, M. A., 2013. Effect of different irrigation coefficients on cane and sugar yield attributes of sugarcane. Crop Environ. 4, 46-50.

Gill, R.S., Madhu Meeta, Thind, K.S., Kumar, B., 2007. Identification of red rot resistant promising crosses. Sugar Tech. 9, 321-324.

Hemaprabha, G., Nagarajan, R., Alarmelu, S., 2004. Response of sugarcane genotypes to water deficit stress. Sugar Tech. $6,165-168$.

Hemaprabha, G., Nagarajan, R., Alarmelu, S. and Natarajan, U. S., 2006. Parental potential of sugarcane clones for drought resistance breeding. Sugar Tech. 8, 59-62.

Inman-Bamber, N. G., Smith, D. M., 2005. Water relations in sugarcane and response to water deficits. Field Crops Res. 92, 185-202.

Jalaja, N.C., Sreenivasan, T.V., Pawar, S.M., Bhoi, P.G., Garkar, R.M., 2006. Co 94012-a new sugarcane variety through somaclonal variation. Sugar Tech. 8(2\&3), 132136.

Liu, M.C., Huang, Y.J., Shih, S.C., 1972. The in vitro production of plants from several tissues of Saccharum spp. J. Agric. Assoc. China. 77, 52-58.

Krishnamurthy, M., 1977. Sugarcane improvement through tissue culture. Proc. Int. Soc. Sugarcane Technol. 16, 23-28.

Murashige, T., Skoog, F., 1962. A revised medium for rapid growth and bioassays with tobacco tissue cultures. Physiol. Plant. 15, 473-479.
Nickell, L.G., 1964. Tissue culture and cell culture of sugarcane: Another research tool. Hawaiian Planters Rec. 57, 223-229.

Nickell, L.G., 1967. Tissue and cell culture for sugarcane research. Proc. Int. Soc. Sugarcane Technol. 12, 887-892.

Pankaj Kumar, Agrawal, A., Tiwari, A. K., Lal, M., Jabri, M.R.A., 2012. Possibilities of development of red rot resistance in sugarcane through somaclonal variation. Sugar Tech. 14(1), 68-75.

Silva, M.A., da Silva, J.A.G., Enciso, J., Sharma, V., Jifon, J., 2008. Yield components as indicators of drought tolerance of sugarcane. Sci. Agric. 65, 620-627.

Singh, G.S., Sandhu, K., Madhu Meeta, Singh, K., Gill, R., Gosal, S.S., 2008. In vitro induction and characterization of somaclonal variation for red rot and other agronomic traits. Euphytica. 160(1), 35-47.

Singh, P. N., Dey, P., Bhatnagar, V. K., Singh, R. D., 2001. Effect of press mud, FYM and irrigation regimes on water use, yield and quality of sugarcane. Ind. J. Sugar Technol. 12, 46-51.

Singh, R. D., Singh, P. N., Kumar, A., 2006. Evaluation of sugarcane (Saccharum officinarum L.) genotypes under variable water regimes. Ind. J. Crop Sci. 1, 142-145.

Smith, M. A., Singels, A., Antewerpen, R., 2005. Differences in canopy development of two sugarcane cultivars under conditions of water stress. Preliminary results. In: Proceedings of the $78^{\text {th }}$ Annual Congress of South African Sugar Technologists Association, held at Kwashukela, Mount Edgecombe, South Africa. pp.149-152.

Sreenivasan, T.V., Jalaja, N.C., 1995. Utility of tissue culture technology in sugarcane improvement. In: Application of Biotechnology for Sustainable Sugarcane Production. Ann. Conv. DSTA Pune. 44, 1-9.

Tiwari, A.K., Bharti, Y.P., Mishra, N., Tripathi, S., Lal, M., Sharma, P.K., Rao, G.P., Sharma, M.L., 2010. Biotechnological approaches for improving sugarcane crop with special reference to disease resistance. Acta Phytopathol. Entomol. Hungrica. 45, 235-249.

Vasantha, S., Alarmelu, S., Hemaprabha, G., Shanthi, R. M., 2005. Evaluation of promising sugarcane genotypes for drought. Sugar Tech. 7(2/3), 82-83.

Wang, W. B., Altman, A., 2003. Plant response to drought, salinity and extreme temperature towards genetic engineering for stress tolerance. Int. J. Plant Biol. 218(1), $1-14$.

Watanabe, K. N., 2002. Challenges in biotechnology for abiotic stress tolerance on roots and tubers. Genetic engineering of crop plants for abiotic stress. Proceeding of an APECJIRCAS Joint Symposium and Workshop, Bangkok, Thailand, 3-7 September 2001. JIRCAS Working Report. 23, 75-83.

\section{How to cite this article:}

Tawar, P. N., Sushir, K. V., Meti, N. T., 2016. Somaclonal variation an aid for sugarcane improvement. Int. J.

Curr. Res. Biosci. Plant Biol. 3(7), 47-55. doi: http://dx.doi.org/10.20546/ijcrbp.2016.307.008 